\title{
MEDICAL AND SURGICAL MANAGEMENT OF ORBITAL CELLULITIS IN CHILDREN
}

Ronit Friling ${ }^{1,7}$, Ben-Zion Garty ${ }^{4,7 *}$, Liora Kornreich ${ }^{2,7}$, Oded Scheurman ${ }^{4,7}$, Murat Hasanreisoglu ${ }^{6}$, Irit Taler ${ }^{4,7}$, Jacob Amir ${ }^{5,7}$, Gilat Livni ${ }^{3,7}$ and Moshe Snir ${ }^{1,6,7}$

${ }^{1}$ Pediatric Ophthalmology Unit, ${ }^{2}$ Department of Imaging, Departments of Pediatrics ${ }^{3} \mathrm{~A},{ }^{4} \mathrm{~B}$, and ${ }^{5} \mathrm{C}$, Schneider Children's Medical Center of Israel, Petach Tikva, ${ }^{6}$ Department of Ophthalmology, Rabin Medical Center, Beilinson Campus, Petach Tikva, ${ }^{7}$ Sackler School of Medicine, Tel Aviv University, Tel Aviv, Israel

\section{ТЕРАПЕВТИЧЕСКОЕ И ХИРУРГИЧЕСКОЕ ЛЕЧЕНИЕ ОРБИТАЛЬНОГО} ЦЕЛЛЮЛИТА ДЕТЕЙ

Ронит Фрилинг ${ }^{1,7}$, Бен-Цион Гарти ${ }^{4,7 *}$, Лиора Корнреич ${ }^{2,7}$, Одед Шеурман ${ }^{4,7}$, Мурат Хасанреисоглу ${ }^{6}$, Ирит Талер ${ }^{4,7}$, Якоб Амир ${ }^{5,7}$, Гилат Ливни ${ }^{3,7}$, Моше Снир ${ }^{1,6,7}$

${ }^{1}$ Детский блок Офтальмологии, ${ }^{2}$ Отдел образной диагностики, Отдель педиатрии ${ }^{3} A,{ }^{4} B, u{ }^{5} C$, Детский Медииинский Центр Шнайдер Израиля, Петах-Тиква, ${ }^{6}$ Отделение офтальмологии, Рабин медицинский центр, Бейлинсон Кампус, Петах-Тиква, ${ }^{7}$ Sackler Школа медицины, Университет ТельАвива, Тель-Авив, Израиль

\begin{abstract}
OвJеCтIVE: The purpose of this study was to identify features of orbital cellulitis that predict response to conservative treatment without surgical intervention and factors associated with a decision for surgery.

Patients and Methods: The medical files of patients diagnosed with orbital cellulitis at a tertiary medical center in central Israel between 1995 and 2010 were reviewed for clinical data, diagnosis, complications, and type of treatment. Comparison was made between patients treated with antibiotics and patients treated with antibiotics and surgery.

Results: Fifty-one patients (35 male) with a mean age of 6.1 years were identified. Main clinical signs included fever (mean $38.5^{\circ} \mathrm{C}$ ), proptosis $(82.3 \%)$, extraocular motility restriction $(74.5 \%)$, and ocular pain $(41.1 \%)$. Fortyone patients were successfully treated with antibiotics and 10 required endoscopic sinus surgery. On betweengroup comparison, the surgery group had severe eye pain $(\mathrm{p}=0.009)$, severe proptosis $(\mathrm{P}=0.02)$, longer intravenous antibiotic treatment $(13.2$ vs. 9.2 days, $p=0.04)$, and several imaging findings. Additional factors associated with surgical intervention included older children, subperiorbital abscess, larger dimension of the abscess (mean $15 \mathrm{~mm}$ ), involvement of frontal sinuses and findings of intraorbital air bubbles. There was no visual deterioration in either group and no late sequelae.

Conclusion: Factors associated with surgery included age older than 9 years, severe ocular pain, severe proptosis, and subperiorbital large abscess. These may be used for early identification of patients at risk of failure of only medical management.
\end{abstract}

Key words: orbital cellulitis, treatment, children

Folia Medica 2014; 56(4): 253-258

Copyright (C) 2014 Medical University, Plovdiv

\section{РЕЗЮМЕ}

ЦЕль: Целью данного исследования является определение характеристик орбитального целлюлита, которые предсказывают эффект консервативного лечения без хирургического вмешательства и поиск факторов, обосновывающих выбор хирургического лечения.

МЕтоды: Медицинская документация пациентов с диагнозом орбитального целлюлита в медицинском центре третьего уровня компетенции в центральной части Израиля за период, охватывающий 1995-2010 гг., была обследована на предмет клинических данных, диагноза, осложнений и методики лечения. Было проведено сравнение между пациентами, прошедшими лечение только антибиотиками и пациентами, прошедшими лечение антибиотиками и хирургическим вмешательством.

Результаты: К исследованию были привлечены пациенты в количестве 51 человек (35 мальчиков) в среднем возрасте 6.1 лет. Основными клиническими признаками являются темепература (в среднем $38.5^{\circ}$ C), проптоз (82.3\%), паралич экстраокулярных мышц (74.5\%), и глазная боль $(41.1 \%)$. Сорок один пациент прошёл успешно курс лечения антибиотиками, а 10 пацентам провели эндоскопическую операцию на синусах. Внутригрупповое сравнение показало, что среди пациентов, прошедших хирургическое лечение наблюдались сильные глазные боли ( $\mathrm{p}=0.009)$, тяжёлый проптоз $(\mathrm{p}=0.02)$, более длительное внутривенное лечение антибиотиками $(\mathrm{p}=0.009)$ и известное количество находок при образном

Article's history: Received: 24 Nov 2014; Received in a revised form: 16 Dec 2014; Accepted: 18 Dec 2014

*Correspondence and reprint request to: Ben-Zion Garty, Department of Pediatrics B, Schneider Children's Medical Center of

Israel; E-mail: garty@clalit.org.il; gartyb@gmail.com;Tel.: 97239253681

14 Kaplan St., Petach Tikva 492020, Israel 
исследовании. Дополнительными факторами, связанными с хирургическим вмешательством, являются включение детей более старшего возраста, субпериорбитальные абсцессы, увеличенный размер абсцесса (в среднем 15 мм), поражение передних участков синусов и находки в виде интраорбитальных воздушных пузырьков. Отсутствуют данные об ухудшении зрения или последующих осложнениях в обеих группах.

ЗАключениЕ: Среди факторов, связанных с хирургическим вмешательством, можно назвать возраст старше 9 лет, сильную глазную боль, тяжёлый проптоз и увеличенный субпериорбитальный абсцесс. Они могут быть использованы для раннего определения тех пациентов, при лечении которых допустим риск провала лечения с применением единственно консервативного подхода.

Ключевые слова: орбитальный изеллюлит, лечение, дети

Folia Medica 2014; 56(4): 253-258

(C) 2014 Все права защищены. Медицинский университет, Пловдив

\section{INTRODUCTION}

The anatomic separation of the soft tissues of the eyelid from those of the orbit, by the orbital septum, helps clinicians to differentiate preseptal from postseptal infections. Preseptal cellulitis (periorbital cellulitis) occurs anterior to the orbital septum and may result from trauma, contiguous infection, or primary bacteremia. ${ }^{1,2}$ In postseptal infection (orbital cellulitis), the infection is localized posterior to the orbital septum, and is usually formed by extension of acute infection from the anatomically close paranasal sinuses. Retrograde spread of orbital cellulitis may lead to severe complications, such as endophthalmitis, cavernous sinus thrombosis, subdural empyema, meningitis, and brain abscess. ${ }^{3-5}$ Complications may also result from osteitic bone destruction or thrombophlebitis of the communicating veins. ${ }^{6}$ Disease of the ethmoid sinus is more often associated with complications owing to the thinness of the lamina papyracea and the valveless structure of the ophthalmologic venous system. ${ }^{7,8}$ The association of infection of multiple sinuses and the appearance of orbital cellulitis is well recognized in the ophthalmic literature. ${ }^{2}$

The current approach to the treatment of orbital cellulitis consists of the prompt administration of intravenous antibiotics and close monitoring of the pupillary reaction and visual status. Surgical drainage is usually considered for patients who fail to improve within $48-72$ hours and its aim is to prevent potentially catastrophic visual impairment or intracranial complications.

Subperiosteal abscess occurs in approximately $15 \%$ of children with orbital cellulitis. Despite intensive antimicrobial and surgical management, visual impairment was reported to develop in $14 \%$ to $33 \%$ of patients with subperiosteal abscess. ${ }^{1}$ These findings have raised a major dilemma among clinicians. On the one hand, early surgical treatment might be expedited in patients considered unlikely to benefit from conventional antibiotic treatment. On the other hand, the early identification of patients who do not need surgical management is important to avoid unnecessary invasive procedures.

\section{AIM}

The objective of the present study was to identify clinical, laboratory, and imaging factors that may predict a high or low likelihood of resolution of orbital cellulitis with conventional treatment, in order to assist clinicians in early decision-making regarding the need for surgical intervention.

\section{PATIENTS AND METHODS}

The medical files of all patients hospitalized in Schneider Children's Medical Center of Israel, a tertiary medical center in central Israel, with a diagnosis of orbital cellulitis, from 1995 to 2010 were reviewed. Children with anatomic abnormalities of the orbit or sinuses, post-traumatic sinusitis, allergic reactions, malignancy, or immunosuppressed state were excluded. A few children with a clinical diagnosis of orbital cellulitis who did not undergo orbital computed tomography (CT) scan were also excluded because of uncertain diagnosis.

The data collected from the patient files included demographic parameters: age, gender, and clinical parameters: fever, ocular pain, ocular motility, strabismus, diplopia, proptosis, decreased visual acuity, laboratory findings [C-reactive protein (CRP), leukocyte count], and CT scan finding.

All the CT scans were reviewed and evaluated by a pediatric radiologist (L.K.) for the following parameters: side of involvement; preseptal, postseptal, and intraconal involvement, paranasal sinus opacification and mucosal thickening, opacification of the sinuses, and extension of orbital inflammation. Thickened or displaced extraocular muscles 
(recti and oblique) were measured quantitatively. Proptosis was graded as mild, moderate, or severe according to the globe displacement toward the anterior border of the bony orbit.

The patients were divided into 2 groups: those who received conservative (medical) treatment only and those treated by both medication and surgery. The groups were compared for general and ophthalmic signs as well as imaging findings.

The study was approved by the Helsinki Committee of Beilinson Hospital and Schneider Medical Center.

\section{STATISTICAL ANALYSIS}

The data were analyzed using BMDP software. Since the sample size was relatively small and the variables did not have a Gaussian distribution, we compared continuous variables between groups using the nonparametric Mann-Whitney U test. Discrete variables were compared with Pearson correlation or chi-square or Fisher's exact test (2-tail). A $P$ value of $\leq 0.05$ was considered significant.

\section{RESULTS}

The study cohort consisted of 51 patients, 35 male $(68.6 \%)$ and 16 female $(31.4 \%)$ with a mean age of 6.1 years (range 0.5 to 17 years). Mean age for males was 7 years (range 1-15), and for females, 4.2 years (range $0.5-17)(P=0.03)$. The right orbit was involved in 25 children (49.0\%) and the left, in $26(51.0 \%)$. Presenting signs included proptosis in 42 patients $(82.3 \%)$, extraocular motility restriction in $38(74.5 \%)$, ocular pain in $20(39 \%)$, and fever $\left(>38^{\circ} \mathrm{C}\right)$ in all 51 patients $(100 \%)$. The ethmoidal sinuses were involved in $96 \%$ of patients, the maxillary sinuses, in $92 \%$, and the frontal sinuses, in $20 \%$.

Initial empiric antibiotic treatment of the patients consisted of intravenous ceftriaxone and clindamycin. After several days of intravenous antibiotic treatment, if the clinical signs resolved/improved, the treatment was changed to first- (cefazolin) or second-generation (cefuroxime) cephalosporins. Surgical drainage was performed after initial medical therapy in cases of visual impairment, afferent pupillary defect, extraocular motility restriction,

Table 1. Clinical findings in children with orbital cellulitis according to treatment modality

\begin{tabular}{|c|c|c|c|}
\hline & Medically treated & $\begin{array}{c}\text { Medically+surgically } \\
\text { treated }\end{array}$ & $P$ value \\
\hline Number of patients $(\%)$ & $41(80 \%)$ & $10(20 \%)$ & \\
\hline Male/female & $26 / 15$ & $9 / 1$ & 0.14 \\
\hline Age $(\mathrm{yr})$, mean $\pm \mathrm{SD}$ & $5.3 \pm 3.4$ & $9.6 \pm 5.2$ & 0.006 \\
\hline \multicolumn{4}{|l|}{ Eye involved } \\
\hline Right & $23 / 41$ & $6 / 10$ & 1.00 \\
\hline Left & $18 / 41$ & $4 / 10$ & 1.00 \\
\hline RAPD & $41 / 41$ & $10 / 10$ & 1.00 \\
\hline Extraocular motility restriction & $30 / 41$ & $8 / 10$ & 0.70 \\
\hline Severe ocular pain & $12 / 41$ & $8 / 10$ & 0.009 \\
\hline Proptosis* & $23 / 41$ & $10 / 10$ & 0.009 \\
\hline Body temperature, $\mathrm{C}^{0}($ mean $\pm \mathrm{SD})$ & $38.4 \pm 1.2$ & $38.7 \pm 1.0$ & 0.48 \\
\hline C-reactive protein $(\mathrm{mg} / \mathrm{L})$ & $6.6 \pm 3.7$ & $10.5 \pm 5.4$ & 0.04 \\
\hline **White blood count (cells $/ \mathrm{mm})$ & $18 \times 10^{4} \pm 0.6 \times 10^{4}$ & $14 \times 10^{4} \pm 0.6 \times 10^{4}$ & 0.19 \\
\hline $\begin{array}{l}\text { **Intravenous treatment }- \text { duration (days) } \\
\text { (median, range) }\end{array}$ & $9.0(2-18)$ & $10.5(6-29)$ & 0.039 \\
\hline $\begin{array}{l}* * \text { Total treatment }- \text { duration (days) (me- } \\
\text { dian, range) }\end{array}$ & $18.0(7-28)$ & $22.5(13-36)$ & 0.050 \\
\hline
\end{tabular}

RAPD-relative afferent pupillary defect as an indication of the involvement of the optic nerve

*By clinical evaluation.

**Using nonparametric Mann-Whitney test. 
severe ocular proptosis with progression, findings of severe orbital pathology on CT scan or lack of clinical improvement within 48 hours of treatment.

Forty-one children were treated with conservative treatment only (80.3\%) and 10 required further endoscopic sinus surgery (19.6\%) (Table 1). The mean duration of intravenous antibiotic treatment was 9.2 days in the medically-treated group and 13 days in the surgically-treated group $(P=0.005)$. The mean duration of the whole antibiotic regimen (intravenous + oral) was 17.5 days and 22 days, respectively $(P=0.05)$.

Mean age of the medically-treated group was 5.3 years (range $0.5-15$ years) and of the surgically-treated group, 9.6 years (range 1-17 years) $(P=0.085)$. There was no sequential decrease in visual acuity in either group. Periorbital edema was observed in both groups equally. The complaint of severe pain was significantly higher in the surgically-treated group ( $8 / 10$ patients, $80 \%$ ) versus the conservative-treated patients, $12 / 41,29 \%(P=$ $0.009)$. The mean body temperature on admission was $38.4^{\circ} \mathrm{C}$ in the medically-treated group and $38.7^{\circ} \mathrm{C}$ in the surgically-treated group and was not statistically significant. The mean white cell count was 17,800 cells $/ \mathrm{mm}$ in the medically-treated group and 14,500 cells $/ \mathrm{mm}$ in the surgically-treated group. The difference was not statistically significant. The mean CRP of the surgically-treated group was $10.5 \mathrm{mg} / \mathrm{dL}$ compared to $6.6 \mathrm{mg} / \mathrm{dL}$ in the conservatively-treated patients. Pathogens were not identified in cultures obtained from the surgical group, probably because of the massive preoperative antibiotic treatment. Polymerase chain reaction for bacteria from the surgical specimen was not routinely performed. All our patients, from both groups, recovered completely without intracranial complications or visual loss.

All 51 patients underwent thin-slice $(2-3 \mathrm{~mm})$ axial CT scans of the orbits, 42 with contrast medium injection; reconstructions were available in 40 patients (Table 2). Proptosis of mild-to-moderate degree was found in $61 \%$ of the medically-treated group. Moderate-to-severe proptosis was observed in $100 \%$ of the surgically-treated group. The incidence of proptosis was statistically significantly higher in the surgically treated patients, although the difference in the degree of proptosis was not (data not shown).

Other CT scan parameters that showed a statistically significant difference between the medically- and surgically-treated groups were: a. rate of subperiosteal abscess; b. mediolateral abscess diameter; c. intraorbital superior rectus muscle displacement; $d$. intraorbital air bubbles (suggestive of anaerobic bacterial infection). The craniocaudal diameter of the abscess was larger in the operated patients, but the difference did not reach statistical significance. There was no between-group difference in aeration of the ethmoidal, maxillary, and sphenoid sinuses, ipsilaterally or contralaterally.

\section{DISCUSSION}

The present study sought to identify factors that could predict responsiveness/nonresponsiveness to medical treatment of orbital cellulitis. We found that the patients who ultimately required surgery were older (mean age 9.5 years), had prominent proptosis,

Table 2. Computed tomography findings in children with orbital cellulitis according to treatment modality

\begin{tabular}{lccc}
\hline & $\begin{array}{c}\text { Medically treated } \\
(\mathbf{n}=\mathbf{4 1})\end{array}$ & $\begin{array}{c}\text { Medically+surgically } \\
\text { treated } \\
\mathbf{( n = 1 0 )}\end{array}$ & p value \\
\hline Proptosis* & $25(61 \%)$ & $10(100 \%)$ & 0.021 \\
Subperiosteal abscess & $13(32 \%)$ & $7(70 \%)$ & 0.036 \\
$\begin{array}{l}\text { Mediolateral abscess diameter (mm), } \\
\text { mean (range) }\end{array}$ & $3.3(1-8)$ & $15.1(4-30)$ & 0.006 \\
Superior rectus displacement & None & $4(40 \%)$ & 0.001 \\
Opacified frontal sinus & $6(15 \%)$ & $4(40 \%)$ & 0.09 \\
Undeveloped frontal sinus & $33(80 \%)$ & $4(40 \%)$ & 0.018 \\
Intraorbital air bubbles & None & $2(20 \%)$ & 0.035 \\
\hline
\end{tabular}

*By radiographic examination. 
larger subperiosteal abscesses, extraocular muscle involvement, and higher CRP. Additional findings in this group were the presence of intraorbital air bubbles and the presence of already developed frontal sinuses.

Rudloe et al. ${ }^{9}$ presented an algorithm to stratify the risk factors for significant complications of patients with orbital cellulitis who presented without classic symptoms or clinical findings. Their results show that absolute neutrophil count of $>10,000$ cells $/ \mathrm{ml}$, moderate to severe periorbital edema, absence of conjunctivitis as the presenting symptom, age $>3$ years, and previous antibiotic use were predictors of orbital abscess. Edema extending beyond the eyelid margins was thought to be a strong predictor for a need of surgery by $\mathrm{Vu}$ et al. ${ }^{10}$ Smith et al. ${ }^{11}$ found that risk factors associated with surgery included age older than 9 years (exactly as in our study), proptosis, extraocular mobility restriction and elevated intraocular pressure. In our study, high white blood cell count, and the degree of fever were not found to be statistically significant factors in predicting a need for surgery, although in our surgically-treated group, the white blood cell count was higher than in the medically-treated group.

Harris $^{12}$ reported on the correlation between successful nonsurgical management of orbital subperiosteal abscess and the presence of 4 criteria: age less than 9 years; no visual impairment; medial abscess of modest size; and no intracranial or frontal involvement. Similar criteria for successful medical treatment were observed also in our study.

The current accepted classification of orbital cellulitis is based on clinical signs of disease extension, ranging from periseptal cellulitis to cavernous sinus thrombosis. ${ }^{13}$ Valesco e Cruz et al. ${ }^{14}$ proposed a new, 3-stage, classification based on imaging findings: diffuse infiltration, subperiosteal abscess, and orbital abscess. However, none of our patients had a diffuse infiltration, defined as obliteration of the muscles and the optic nerve by a homogeneous mass.

The male predominance in our study or orbital cellulitis, with a male to female ratio of $3: 1$ was observed also by other authors. ${ }^{2,8}$ This finding is in accordance with the trends of more serious childhood infections in males.

In our study, the mean age of surgically-treated patients was 9.6 years versus 5.3 years in the medically-treated group. Similar age differences were observed also by other authors ${ }^{11,12}$ who reported that in children older than 9 years, there is a trend towards a more complex clinical course, which is refractory to antibiotic treatment alone, and therefore will need surgical intervention.

Our surgically-treated group had a significant preponderance of male patients: $90 \%$ versus $63.4 \%$ in the medically-treated group. This is also in accordance with other series that provided gender-specific data. ${ }^{15,16}$ None of the patients in our surgically-treated group had complications of the surgery or needed additional intervention, as opposed to an earlier study which reported a $10 \%$ rate of re-operation. ${ }^{17}$

Proptosis, detected on CT scans, was found significantly more often in the surgically-treated group of patients in our study. Additionally, subperiosteal abscess was identified in $70 \%$ of the children who underwent surgery and only $30 \%$ of those who did not. Garcia and Harris ${ }^{18}$ considered a "large" subperiosteal abscess as an indication for surgery, but did not quantify its size. Our surgically-treated group had larger abscesses than the nonoperated patients (mean diameter $15.1 \mathrm{~mm}$ vs. $3.5 \mathrm{~mm}$, respectively). In another study ${ }^{19}$, the mean width of the abscesses that underwent drainage was 14.6 $\mathrm{mm}$, which was very close to our mean value of $15.1 \mathrm{~mm}$.

Limitation of extraocular muscle motility is a worrisome $\operatorname{sign}^{19}$, as is the involvement of multiple extraocular muscles ${ }^{2}$. In our series, the surgically treated group had a significantly higher incidence of superior and lateral rectus muscle involvement. Two of our patients had intraorbital air bubbles, compatible with anaerobic infection, commonly considered an indication for surgery. ${ }^{18}$

Finally, frontal sinusitis may be a risk factor for intracranial extension ${ }^{19}$ and an indication for surgery ${ }^{18,20}$. This is supported by our finding of a significantly higher rate of opacification of the frontal sinus in the surgically-treated patients.

According to the guidelines of the American Association of Pediatrics (AAP) ${ }^{17}$, patients with orbital cellulitis should be treated with antibiotic drugs targeted against the common sinus pathogens (Streptococcus pneumoniae, Haemophilus influenzae and Moraxella catarrhalis). At our hospital, patients were routinely treated with ceftriaxone and clindamycin, which together covered the common pathogens, including penicillin-resistant S. pneumonia, anaerobic bacteria, and Staphylococcus aureus.

The optimal duration of antimicrobial treatment in patients with orbital cellulitis is not determined in the medical literature. The mean duration of total antibiotic treatment in our patients ranged from 17 days in the medically-treated group to 
22 days in the surgically-treated group. In the surgically-treated group, the mean duration of intravenous antibiotic treatment was 13 days while in the medically-treated group, only 9 days. This difference probably reflects the more severe course of the surgically-treated patients.

The ophthalmic literature reports that even with appropriate antibiotic treatment, orbital cellulitis is associated with a high risk of complications (20\%) and a visual loss rate of $14 \%$ to $33 \% .{ }^{1}$ The visual loss may be secondary to elevated intraorbital pressure resulting from central artery occlusion and consequent retinal ischemia, or due to optic neuritis induced by the extensive orbital-sinus infection. However, we did not observe these complications in our patients.

\section{CONCLUSIONS}

Our study is limited because of the relatively small number of operated patients. However, several factors were found to be associated with the need for surgery, including age of the patient, prominent proptosis, severe ocular pain, presence of subperiorbital abscess, dimension of the abscess, involvement of frontal sinuses, and the presence of intraorbital air bubbles.

\section{REFERENCES}

1. Osguthorpe JD, Hochman M. Inflammatory sinus diseases affecting the orbit. Otolaryngol Clin North Am 1993;26:657-71.

2. Rahbar R, Robson CD, Petersen RA, et al. Management of orbital subperiosteal abscess in children. Arch Otolaryngol Head Neck Surg 2001;127:281-6.

3. Connell B, Raral S, McNob AA. Fulminant orbital cellulitis with complete visual loss. Clin Exp Ophthalmol 2001;29:260-1.

4. Gans H, Sekula J, Wlodyka J. Treatment of acute orbital complications. Arch Otolaryngol 1974;100: 329-32.

5. Morgan PR, Morrison WV. Complications of frontal and ethmoid sinusitis. Laryngoscope 1980;90:661-6.

6. Teele DW. Management of the child with a red and swollen eye. Pediatr Infect Dis 1983;2:258-62.

7. Schramm VL, Myers EN, Kennerdell JS. Orbital complications of acute sinusitis: evaluation, management, and outcome. Otolaryngology 1978;86:221-30.
8. Arjmand EM, Lusk RP, Muntz HR. Pediatric sinusitis and subperiosteal abscess formation: diagnosis and treatment. Otolaryngol Head Neck Surg 1993;109:886-94.

9. Rudloe TF, Harper MB, Prabhu SP, et al. Acute periorbital infections: who needs emergent imaging? Pediatrics 2010;125:e719-26.

10. Vu BL, Dick PT, Levin AV, Pirie J. Development of a clinical severity score for preseptal cellulitis in children. Pediatr Emerg Care 2003;19:302-7.

11. Smith JM, Bratton EM, Dewitt P, et al. Predicting the need for surgical intervention in pediatric orbital cellulitis. Am J Ophthalmol 2014;158:387-94.

12. Harris GJ. Age as a factor in the bacteriology and response to treatment of subperiosteal abscess of the orbit. Transplantation Am Ophthalmol Soc 1993;91:441-516.

13. Chandler JR, Langenbrunner DJ, Stevens ER. The pathogenesis of orbital complications in acute sinusitis. Laryngoscope 1970;80:1414-28.

14. Velasco e Cruz AA, Demarco RC, Valera FC, et al. Orbital complications of acute rhinosinusitis: a new classification. Braz J Otorhinolaryngol 2007;73: 684-8.

15. Sajjadian A, Chundru U, Isaacson G. Prospective application of a protocol for selective nonsurgical management of suspected orbital subperiosteal abscesses in children. Ann Otol Rhinol Laryngol 1999;108:459-62.

16. Brown CL, Graham SM, Griffin MC, et al. Pediatric medial subperiosteal orbital abscess: medical management where possible. Am J Rhinol 2004;18:321-7.

17. American Academy of Pediatrics. Clinical practice guidelines: management of sinusitis. Pediatrics 2001;108:798-808.

18. Garcia GH, Harris GJ. Criteria for nonsurgical management of subperiosteal abscess of the orbit: analysis of outcomes 1988-1998. Ophthalmology 2000;107:1454-6; discussion 1457-8.

19. Oxford LE, McClay J. Medical and surgical management of subperiosteal orbital abscess secondary to acute sinusitis in children. Int J Pediatr Otorhinolaryngol 2006;70:1853-61.

20. Herrmann BW, Forsen JW Jr. Simultaneous intracranial and orbital complications of acute rhinosinusitis in children. Int J Pediatr Otorhinolaryngol 2004;68:619-25. 